\title{
Halogen atom effect on photophysical and photodynamic characteristics of derivatives of 5,10,15,20-tetrakis(3-hydroxyphenyl)porphyrin
}

\author{
A.C. Serra ${ }^{a}$, M. Pineiro ${ }^{\text {a }}$, A.M.d'A. Rocha Gonsalves ${ }^{\mathrm{a}, *}$, M. Abrantes ${ }^{\mathrm{b}}$, M. Laranjo $^{\mathrm{b}}$, A.C. Santos $^{\mathrm{b}}$, M.F. Botelho ${ }^{\mathrm{b}}$ \\ ${ }^{a}$ Chymiotechnon, Departamento de Química, Universidade de Coimbra, 3004-535 Coimbra, Portugal \\ ${ }^{\mathrm{b}}$ Instituto de Biofisica/Biomatemática, CIMAGO, IBILI, Faculdade de Medicina de Coimbra, 3000-354 Coimbra, Portugal
}

\section{A R T I C L E I N F O}

\section{Article history:}

Received 27 July 2007

Received in revised form 21 January 2008

Accepted 23 April 2008

Available online $\mathrm{xxxx}$

\section{Keywords:}

Halogenated porphyrins

Photodynamic therapy

Heavy atom effect

\begin{abstract}
A B S T R A C T
Brominated and iodinated derivatives of 5,10,15,20-tetrakis(3-hydroxyphenyl)porphyrin were synthesised directly from the corresponding aldehydes. Photophysical and photochemical properties, singlet oxygen formation quantum yields, photobleaching and $\log P$ were measured. Cellular uptake measurements and cytotoxicity assays on WiDr and A375 tumour cell lines were performed. 5,10,15,20-Tetrakis(2-bromo-5-hydroxyphenyl)porphyrin showed the best cytotoxicity with values of $\mathrm{IC}_{50}$ of $113 \mathrm{nM}$ over WiDr cells and $52 \mathrm{nM}$ over A375 cells.
\end{abstract}

(c) 2008 Elsevier B.V. All rights reserved.

\section{Introduction}

Photodynamic therapy (PDT) is accepted as one of the several methods available for cancer treatment. The generation of the active oxygen species near the target and only in the presence of light minimizes the particularly important side effects of the common systemic drugs. Of course there are some problems associated with the presence of a light sensitive drug, sensitizer, in the organism and with the light dose required for the elimination of the cancer cells which can damage normal cells. Therefore searching for sensitizers which can reduce these secondary events is important. Due to their unique photochemical characteristics, the porphyrin family compounds are the major class of molecules used as sensitizers in PDT [1-5]. The ability to penetrate cells, together with the capacity for singlet oxygen generation are essential characteristics of the sensitizer. Tetraarylporphyrins bearing hydroxyl substituents in the aryl group are described as good photodynamic agents. For example, in Foscan ${ }^{\circledR}$, currently in clinical use, all four phenyl groups have a hydroxyl substituent at the meta position [6,7]. One possible way to improve the therapeutic capability of the sensitizers is through the heavy atom effect [8] as shown in azadipyrromethene derivatives [9]. However, in vitro demonstration of the heavy atom effect in porphyrins is not confirmed.

In this work we prepared several new halogenated porphyrins (PS2-PS4) related to 5,10,15,20-tetrakis(3-hydroxyphenyl)porphyrin (PS1) in order to evaluate the heavy atom effect on the

\footnotetext{
* Corresponding author. Tel.: +351 239852082; fax: +351 239826068 .

E-mail address: arg@qui.uc.pt (A.M.d'A. Rocha Gonsalves).
}

photophysical and photochemical properties, as well as the photodynamic effect of these new sensitizers using two different cell lines, WiDr human colon adenocarcinoma cells and melanoma A375 cells.

\section{Experimental}

\subsection{General}

${ }^{1} \mathrm{H}$ NMR spectra were recorded on $300 \mathrm{MHz}$ Bruker-AMX spectrometer. Mass spectra of EI were obtained with GC-MSD HP 6890/ 5973 and Finnigan Advantage for the MS(ESI) spectra. Elemental analysis was carried out with a EA1108-CHNS-0 Fisons Instruments elemental analyser. Absorption spectra were recorded with a Hitachi U-2001 spectrophotometer. Fluence rates were measured with X97 radiometer from Gigahertz-Optik. Irradiation for the photodynamic treatment was made using a fluorescent light source equipped with a red filter $\left(\lambda_{\text {cut off }}<560 \mathrm{~nm}\right)$.

\subsection{Chemicals}

Solvents were purified by standard methods before use. Dichloromethane was dried over $\mathrm{CaH}_{2}$ and distilled. The chloroform was neutralised with neutral active alumina. 9,10-Dimethylanthracene (DMA) was acquired from Aldrich and used without further purification. Methylene Blue was used as received (Riedel-de Haën). 1-Octanol was obtained from Merck. Pyrrole was distilled before used. For column chromatography, Silica Gel 60-220-440 mesh/ 0.035-0.070 mm, from Fluka was used. 3-Hydroxybenzaldehyde 
(1) from Aldrich was recrystallized from water. 2-Bromo-5hydroxybenzaldehyde (2) [10] and 2,4,6-tribromo-3-hydroxybenzaldehyde (4) [11] were prepared by bromination in acetic acid as described. Photofrin ${ }^{\circledR}$ was kindly offered by the Gastroenterology Service of the Hospitais da Universidade de Coimbra. BCA protein assay from Pierce was used for the quantification of the protein.

\subsection{Porphyrin synthesis}

\subsubsection{4-Iodo-3-hydroxybenzaldehyde (3) [12]}

To a solution of $3.6 \mathrm{~g}(0.0295 \mathrm{~mol})$ of $m$-hydroxybenzaldehyde in $40 \mathrm{~mL}$ of ammonia, a solution of $7.5 \mathrm{~g}(0.0300 \mathrm{~mol})$ of iodine in $100 \mathrm{~mL}$ of water with $22.5 \mathrm{~g}$ of potassium iodide is slowly added. The solution is left for $1 \mathrm{~h}$ with stirring. Then a solution of $\mathrm{HCl}$ ( $3 \mathrm{M}$ ) is added until a yellow precipitate is formed. At this time the solution is still alkaline. The liquid is separated, the solution is made acid by addition of $\mathrm{HCl}(3 \mathrm{M})$ and a white precipitate is formed. Filtration and recrystallization from ethanol/water gives $2.8 \mathrm{~g}$ (38\%) of 4-iodo-3-hydroxybenzaldehyde (3) m.p. $125^{\circ} \mathrm{C}$.

${ }^{1} \mathrm{H} \mathrm{NMR}\left(300 \mathrm{MHz}, \mathrm{CDCl}_{3}\right) \delta$-ppm $=6.0(1 \mathrm{H}, \mathrm{s}, \mathrm{OH}), 7.19(1 \mathrm{H}, \mathrm{dd}$, $J=8.0 \mathrm{~Hz}, J=1.9 \mathrm{~Hz}), 7.45(1 \mathrm{H}, \mathrm{d}, J=1.9 \mathrm{~Hz}), 7.89(1 \mathrm{H}, \mathrm{d}, J=8.0 \mathrm{~Hz})$, $9.93(1 \mathrm{H}, \mathrm{s}, \mathrm{CHO})$; EI-MS: $m / z=248\left(\mathrm{M}^{+}\right)$.

\subsubsection{5,10,15,20-Tetrakis(3-hydroxyphenyl)porphyrin (PS1) (THPP)}

3-Hydroxybenzaldehyde $(0.61 \mathrm{~g}, 5.0 \mathrm{mmol})$ and pyrrole $(0.40 \mathrm{~mL}, 5.9 \mathrm{mmol})$ are added to $500 \mathrm{~mL}$ of degassed dichloromethane. One drop of ethanol followed by $10 \mu \mathrm{L}$ of boron trifluoroboroetherate are added and the reaction is left to stand overnight. The reaction is stopped by adding $0.025 \mathrm{~mL}$ of triethylamine. Propionic acid $(60 \mathrm{~mL})$ and $2 \mathrm{~mL}$ of hydrogen peroxide (30\%) are added and the solution concentrated in vacuo to a volume of $150-200 \mathrm{~mL}$. The solution is kept at $40{ }^{\circ} \mathrm{C}$ with stirring until complete oxidation (1-3 h). Organic acid is carefully extracted with water and the organic solution dried over sodium sulphate. The solvent is removed by evaporation and the residue chromatographed on silica gel with dichloromethane/ethyl acetate (2:1) (2\% triethylamine) as mobile phase, giving $100 \mathrm{mg}$ (12\%) of 5,10,15,20-tetrakis(3-hydroxyphenyl) porphyrin, which is recrystallized from dichloromethane/ cyclohexane giving purple crystals.

UV-vis (EtOH), $\left(\lambda_{\max } \mathrm{nm}\right) .415,511,545,585,643 ;{ }^{1} \mathrm{H}$ NMR $\left(300 \mathrm{MHz}, \mathrm{CD}_{3} \mathrm{OD}\right) \delta$-ppm $=-2.85(2 \mathrm{H}, \mathrm{s}, \mathrm{NH}), 7.27-7.29(4 \mathrm{H}, \mathrm{m}$, $\left.\mathrm{H}_{\text {phenyl }}\right), 7.52-7.57\left(8 \mathrm{H}, \mathrm{m}, \mathrm{H}_{\text {phenyl }}\right), 7.68-7.72\left(8 \mathrm{H}, \mathrm{m}, \mathrm{H}_{\text {phenyl }}\right)$, $8.50(4 \mathrm{H}, \mathrm{s}, \mathrm{OH}), 8.90\left(8 \mathrm{H}, \mathrm{s}, \mathrm{H}_{\text {pyrrole }}\right)$; ESI-MS: $m / z=679(\mathrm{M}+1)^{+}$; $\mathrm{C}_{44} \mathrm{H}_{30} \mathrm{O}_{4} \mathrm{~N}_{4}$ : calcd. C, 77.86; H, 4.46; N, 8.25. Found: C, 78.23; H, $4.52 ; \mathrm{N}, 8.30 \%$.

\subsubsection{5,10,15,20-Tetrakis(2-bromo-5-hydroxyphenyl)porphyrin (PS2) $\left(\mathrm{TBr}_{4} \mathrm{HPP}\right)$}

2-Bromo-5-hydroxybenzaldehyde ( $1.0 \mathrm{~g}, 5.0 \mathrm{mmol})$ and pyrrole $(0.34 \mathrm{~mL}, 5.9 \mathrm{mmol})$ are added to $500 \mathrm{~mL}$ of degassed dichloromethane. One drop of ethanol followed by $10 \mu \mathrm{L}$ of boron trifluoroboroetherate is added and the reaction is left overnight. The reaction is stopped by adding $0.025 \mathrm{~mL}$ of triethylamine. Acetic acid $(60 \mathrm{~mL})$ and $2 \mathrm{~mL}$ of hydrogen peroxide (30\%) are added and the solution concentrated in vacuo to a volume of $150-200 \mathrm{~mL}$. The solution is kept at $40{ }^{\circ} \mathrm{C}$ with stirring until complete oxidation $(0.5-1 \mathrm{~h})$. Acetic acid is carefully extracted with water and the organic solution dried over sodium sulphate. The solvent is removed and the residue chromatographed on silica gel with dichloromethane/ethyl acetate (2:1) (2\% triethylamine) as mobile phase giving $120 \mathrm{mg}$ (10\%) 5,10,15,20-tetrakis(2-bromo-5-hydroxyphenyl) porphyrin, which is recrystallized from ethyl acetate/heptane giving purple crystals.

UV-vis (EtOH), ( $\left.\lambda_{\max } \mathrm{nm}\right) .416,512,586,646 ;{ }^{1} \mathrm{H}$ NMR (300 MHz, CD $\mathrm{CD}_{3} \mathrm{OD} \delta$-ppm: $4.63(4 \mathrm{H}, \mathrm{sl}, \mathrm{OH}), 7.19-7.30(4 \mathrm{H}, \mathrm{m}$, $\left.\mathrm{H}_{\text {phenyl }}\right), 7.55-7.72\left(4 \mathrm{H}, \mathrm{m}, \mathrm{H}_{\text {phenyl }}\right), 7.83-7.86\left(4 \mathrm{H}, \mathrm{m}, \mathrm{H}_{\text {phenyl }}\right), 8.8$
(8H, s, $\left.\mathrm{H}_{\text {pyrrole }}\right)$; ESI-MS: $m / z=994(\mathrm{M}+1)^{+} ; \mathrm{C}_{44} \mathrm{H}_{26} \mathrm{O}_{4} \mathrm{Br}_{4} \mathrm{~N}_{4} \cdot \mathrm{H}_{2} \mathrm{O}$ : calcd. C, 52.2; H, 2.79; N, 5.53. Found: C, 52.5; H, 3.13; N, $4.71 \%$.

\subsubsection{5,10,15,20-Tetrakis(4-iodo-3-hydroxyphenyl)porphyrin (PS3) $(\mathrm{TI} 4 \mathrm{HPP})$}

Using 4-iodo-3-hydroxybenzaldehyde and the cyclization-oxidation procedure described above for PS2 we obtain a crude product that is chromatographed on silica gel with dichloromethane/ ethyl acetate (1:1) (2\% triethylamine) as mobile phase yielding $190 \mathrm{mg}$ (13\%) of 5,10,15,20-tetrakis(4-iodo-3-hydroxyphenyl) porphyrin as purple powder.

UV-vis (EtOH), $\left(\lambda_{\max } \mathrm{nm}\right) .418,513,548,588,645 ;{ }^{1} \mathrm{H}$ NMR (300 MHz, CD $\left.\mathrm{CD}_{3} \mathrm{OD}\right) \delta$-ppm: $7.35\left(4 \mathrm{H}, \mathrm{m}, \mathrm{H}_{\text {phenyl }}\right), 7.64(4 \mathrm{H}, \mathrm{m}$, $\left.\mathrm{H}_{\text {phenyl }}\right), 7.82-7.99$ ( $\left.4 \mathrm{H}, \mathrm{m}, \mathrm{H}_{\text {phenyl }}\right), 8.91$ ( $\left.8 \mathrm{H}, \mathrm{s}, \mathrm{H}_{\text {pyrrole }}\right)$; ESI-MS: $m / z=1183(\mathrm{M}+1)^{+} ; \mathrm{C}_{44} \mathrm{H}_{26} \mathrm{O}_{4} \mathrm{I}_{4} \mathrm{~N}_{4} \cdot 4 \mathrm{H}_{2} \mathrm{O}$ : calcd. C, 42.1; $\mathrm{H}, 2.73$; N, 4.47. Found: C, 41.9; H, 2.35; N, 3.78\%.

\subsubsection{5,10,15,20-Tetrakis(2,4,6-tribromo-3-hydroxyphenyl)porphyrin (PS4) ( $\left.\mathrm{TBr}_{12} \mathrm{HPP}\right)$}

Using 2,4,6-tribromo-5-hydroxybenzaldehyde (1.87 g, $5.0 \mathrm{mmol})$ and the cyclization-oxidation procedure described above for PS2 we obtain a crude product that is chromatographed on silica gel with dichloromethane/ethyl acetate (1:1) (2\% triethylamine) as mobile phase yielding $150 \mathrm{mg}$ (7\%) 5,10,15,20-tetrakis(2,4,6-tribromo-5-hydroxyphenyl) porphyrin as a purple solid that was recrystallized from chloroform/cyclohexane.

UV-vis (EtOH), $\left(\lambda_{\max } \mathrm{nm}\right) .418,512,589,649 ;{ }^{1} \mathrm{H} \mathrm{NMR}\left(\mathrm{CD}_{3} \mathrm{OD}\right)$ $\delta$-ppm $=-2.74(2 \mathrm{H}, \mathrm{bs}, \mathrm{NH}), 6.65(4 \mathrm{H}, \mathrm{bs}, \mathrm{OH}), 8.20\left(4 \mathrm{H}, \mathrm{m}, \mathrm{H}_{\text {phenyl }}\right)$, $7.70\left(8 \mathrm{H}, \mathrm{s}, \mathrm{H}_{\text {pyrrole }}\right)$; ESI-MS: $m / z=1626(\mathrm{M}+1)^{+} ; \mathrm{C}_{44} \mathrm{H}_{18} \mathrm{~N}_{4} \mathrm{O}_{4} \mathrm{Br}_{12} \cdot 2$ $\mathrm{CH}_{3} \mathrm{COOCH}_{2} \mathrm{CH}_{3}$ : calcd. C, 34.67; H, 1.90; N, 3.11; Found: C, 34.97; $\mathrm{H}, 1.70$; N, 3.14\%.

\subsection{Singlet oxygen quantum yield measurements}

Photo-oxidation of 9,10-dimethylanthracene (DMA) was used to determine the singlet oxygen formation quantum yield by the sensitizers using steady state photolysis.

\subsubsection{General procedure}

One millilitre of DMA solution $\left(1 \times 10^{-4} \mathrm{M}\right)$ and $2 \mathrm{~mL}$ of sensitizer solution with O.D. at $417 \mathrm{~nm}$, adjusted so that all the sensitizers absorb the same number of photons in the irradiated region [13], were mixed in a quartz cell with $1 \mathrm{~cm}$ path. The sample was air saturated and stirred magnetically to obtain uniform irradiation of the whole sample. The irradiation was performed using a $50 \mathrm{~W}$ halogen lamp, infrared radiation was filtered off through a $5 \mathrm{~cm}$ length water filter and wavelength range from 400 to $600 \mathrm{~nm}$ was selected with appropriate glass filters. Absorption spectra of DMA and the sensitizer solution is simply a superimposition of the spectra of the separate components. DMA photo-oxidation was monitored by the decrease in absorbance at $375 \mathrm{~nm}$ in ethanol. All the solutions were prepared and used without delay. THPP (PS1) was used as standard in ethanol $\left(\Phi_{\Delta}=0.50\right)[14]$.

Singlet oxygen quantum yields for the sensitizers were obtained from the ratio between the slopes of the linear region of the semilogarithmic plot for the absorption decay of DMA $\left(\ln A_{0} / A\right)$ versus time, obtained by a linear least-squares fit when measured from the solutions with the sensitizers and the reference under similar conditions [14-18]. The pooled standard deviation of the kinetic data, using different prepared samples, was less than $10 \%$.

\subsection{Photobleaching}

The porphyrin photobleaching was measured using solutions in $\mathrm{H}_{2} \mathrm{O} / \mathrm{PEG}_{400} /$ EtOH $(50: 30: 20, \mathrm{v} / \mathrm{v} / \mathrm{v})$ with a $5 \times 10^{-6} \mathrm{M}$ concentra- 
tion and the same irradiation source used for the cytotoxicity assays. The value of photodegradation was determined by UV-vis spectroscopy from the decrease of the Soret band $(B(0,0))$ intensity. The total irradiation time was $24 \mathrm{~h}$ and measurements were made at $6 \mathrm{~h}$ intervals.

\subsection{Partition coefficient measurements}

1-Octanol/water partition coefficients were determined at $25^{\circ} \mathrm{C}$ using equal volumes, $3 \mathrm{~mL}$, of water (buffered at $\mathrm{pH}=8$ using sodium tetraborate) and 1-octanol. Typically, $2 \mathrm{mg}$ of sensitizer were dissolved (using ultrasound when necessary) in the pre-equilibrated mixture of solvents and vortexed for $10 \mathrm{~min}$. The solutions were left until the separation between the two phases was clear. The absorption of the aqueous phase was directly measured and the absorption of the solution in 1-octanol was measured from $100 \mu \mathrm{L} / 3 \mathrm{~mL}$ dilutions using UV-vis spectroscopy. The $\log P$ was calculated from the ratio between the absorbance of the two solvents [19].

\subsection{Cell culture conditions}

The human colon carcinoma cell line WiDR and the human melanoma cell line A375 were purchased from American Type Culture Collection. The cell lines were cultured with Dulbecco's Modified Eagle medium (Sigma-Aldrich, Inc; Sigma D-5648) supplemented with $10 \%$ heat-inactivated fetal bovine serum (Gibco Invitrogen Life Technologies; Gibco 2010-04), 1\% Penicillin-Streptomycin (Gibco Invitrogen Life Technologies; $100 \mathrm{U} / \mathrm{mL}$ penicillin and $10 \mu \mathrm{g} / \mathrm{mL}$ streptomycin - Gibco 15140-122) and $100 \mu \mathrm{M}$ sodium pyruvate (Gibco Invitrogen Life Technologies; Gibco 1360) at $37^{\circ} \mathrm{C}$, in a humidified incubator with $95 \%$ air and $5 \% \mathrm{CO}_{2}$.

\subsection{Cellular uptake}

Cells, $1 \times 10^{5}$, were incubated with solutions of the sensitizer of $5 \mu \mathrm{M}, 1 \mu \mathrm{M}$ and $0.5 \mu \mathrm{M}$ concentrations for $24 \mathrm{~h}$, released by trypsinization and washed with cold PBS. To ensure full disaggregation and cell rupture, $5 \mathrm{~mL}$ of methanol was added and the resulting suspension left in the dark for $24 \mathrm{~h}$. The fluorescence intensity of the supernatant was determined by fluorescence spectroscopy with a SPEX fluoromax 322-2 spectrophotometer using $410 \mathrm{~nm}$ excitation wavelength. The intracellular concentration was deter- mined using a calibration curve obtained from the fluorescence intensity in methanol solutions for each sensitizer.

\subsection{Photodynamic treatment}

For each experiment, cells were plated in 48 multiwells (Corning Costar Corp), in a concentration of 40,000 cells/mL and kept in the incubator overnight, in order to allow the attachment of the cells. The formulation of these sensitizers consisted in a $1 \mathrm{mg} / \mathrm{mL}$ solution in a ternary mixture of $\mathrm{H}_{2} \mathrm{O} / \mathrm{PEG}_{400} / \mathrm{EtOH}$ $(50: 30: 20, v / v / v)$, the desired concentrations being achieved by successive dilutions.

The sensitizers were administered in several concentrations ( $50 \mathrm{nM}, 250 \mathrm{nM}, 500 \mathrm{nM}, 1 \mu \mathrm{M}, 5 \mu \mathrm{M}, 10 \mu \mathrm{M}$ ) and cells were incubated for $24 \mathrm{~h}$. Cells were washed with PBS and new drug-free medium was added. Each plate was irradiated with a fluence rate of $7.5 \mathrm{~mW} / \mathrm{cm}^{2}$ until a total of $10 \mathrm{~J}$ was reached. Cell viability was measured $24 \mathrm{~h}$ after the photodynamic treatment.

\subsection{Measurement of cell viability}

The sensitivity of the cell lines to the sensitizers was analyzed using the MTT, (3-(4,5-dimethylthiazol-2-yl)-2,5-diphenyltetrazolium bromide, colorimetric assay (Sigma-Aldrich, Inc.; Sigma M2128) to measure cell proliferation. Cytotoxicity was expressed as the percentage of inhibition of cell proliferation correlated with untreated cultures. This allows the calculation of the concentration that inhibits the culture cell proliferation in $50 \%\left(\mathrm{IC}_{50}\right)$. Each experiment was performed in duplicate and repeated in three sets of tests.

\section{Results}

\subsection{Synthesis of the sensitizers (PS1-PS4)}

Hydroxyphenylporphyrins are usually synthesized from the corresponding methoxyphenylporphyrins followed by standard $\mathrm{BBr}_{3}$ demethylation. This strategy requires the use of the methoxyl derivatives of the aldehydes which are prepared by methylation of the corresponding hydroxybenzaldehydes. Our approach, replacement of DDQ by hydrogen peroxide in the oxidative step of porphyrinogens [20], allows to obtain the hydroxyphenylporphyrins directly from the hydroxylated aldehydes. Although giving lower yields, in our approach two synthetic steps are avoided,

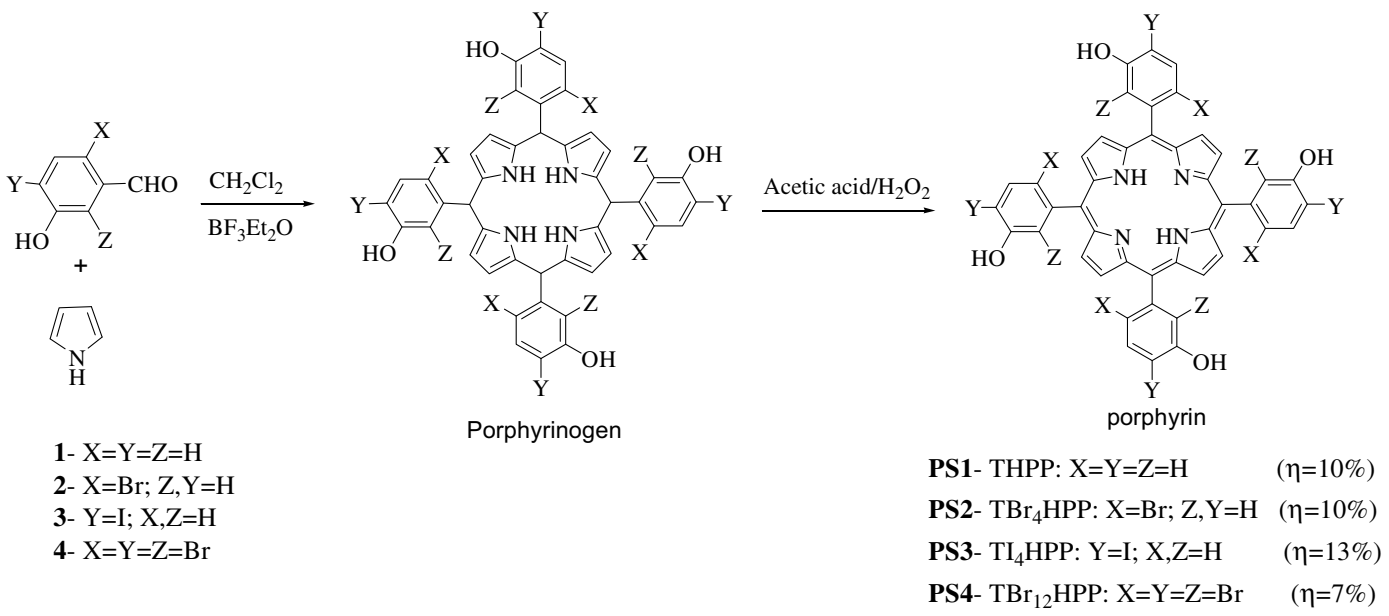

Scheme 1. Synthesis of sensitizers PS1-PS4. 
the protection of the aldehydes and the final deprotection of the porphyrins Scheme 1.

\subsection{Photophysical and photochemical properties}

The absorption spectra of porphyrins in ethanol show the typical Soret $(B(0,0)$ band $)$ and Q-bands of these compounds [21]. The absorption maxima and absorption coefficients of the sensitizers are presented in Table 1 . For concentrations between $1 \times 10^{-7}$ and $1 \times 10^{-4} \mathrm{M}$ no deviation of the Beer-Lambert law was observed indicating that the sensitizers are not aggregated under the experimental conditions. Fig. 1 shows the normalised UV-vis spectra of $\mathrm{TBr}_{4} \mathrm{HPP}, \mathrm{TBr}_{12} \mathrm{HPP}, \mathrm{TI}_{4} \mathrm{HPP}$.

Singlet oxygen formation quantum yield, $\Phi_{\Delta}$, was measured by steady state photolysis using DMA as target. This compound was used in order to calculate the singlet oxygen formation quantum yield of different porphyrins and related compounds [14]. DMA seems to be the best choice because it reacts selectively with $\mathrm{O}_{2}\left({ }^{1} \Delta_{\mathrm{g}}\right)$, the reaction has a large rate constant in water and in many organic solvents [17,22-24], does not present significant photobleaching, the observation of the photo-oxidation of DMA using UVvis spectroscopy is possible without interference of the sensitizer absorption, and the process of photo-oxidation in the presence of sensitizer follows first order kinetics.

With our steady state photolysis system we calculated 0.82 for the $\Phi_{\Delta}$ of Rose Bengal using Methylene Blue as reference and DMA as target in ethanol, the values from the literature differ between 0.68 and 0.86 [14]. Using the photo-oxidation of DMA in ethanol, and THPP (PS1) as reference, we calculated the singlet oxygen formation quantum yields, Table 2 .

Table 1

Absorption characteristics of sensitizers in ethanol

\begin{tabular}{|c|c|c|c|c|c|}
\hline & \multicolumn{5}{|c|}{$\lambda_{\max }(\mathrm{nm}) \varepsilon\left(\mathrm{M}^{-1} \mathrm{~cm}^{-1}\right)$} \\
\hline & $B(0-0)$ & $\mathrm{Qx}(1-0)$ & $\mathrm{Qy}(1-0)$ & $\mathrm{Qx}(0-0)$ & $\mathrm{Qy}(0-0)$ \\
\hline \multirow[t]{2}{*}{ THPP, PS1 } & 415 & 511 & 545 & 585 & 643 \\
\hline & $1.12 \times 10^{5}$ & $1,21 \times 10^{4}$ & $7.63 \times 10^{3}$ & $6.38 \times 10^{3}$ & $4.64 \times 10^{3}$ \\
\hline \multirow[t]{2}{*}{$\mathrm{TBr}_{4} \mathrm{HPP}, \mathbf{P S 2}$} & 416 & 512 & 540 (shoulder) & 586 & 646 \\
\hline & $1.93 \times 10^{5}$ & $1.24 \times 10^{4}$ & $4.50 \times 10^{3}$ & $4.98 \times 10^{3}$ & $2.93 \times 10^{3}$ \\
\hline \multirow[t]{2}{*}{$\mathrm{TI}_{4} \mathrm{HPP}, \mathbf{P S} 3$} & 418 & 513 & 548 & 588 & 645 \\
\hline & $2.20 \times 10^{5}$ & $1.30 \times 10^{4}$ & $6.07 \times 10^{3}$ & $5.03 \times 10^{3}$ & $3.10 \times 10^{3}$ \\
\hline \multirow[t]{2}{*}{$\mathrm{TBr}_{12} \mathrm{HPP}$, PS4 } & 418 & 512 & 540 (shoulder) & 589 & 649 \\
\hline & $1.75 \times 10^{5}$ & $1.47 \times 10^{4}$ & $6.26 \times 10^{3}$ & $6.43 \times 10^{3}$ & $3.40 \times 10^{3}$ \\
\hline
\end{tabular}

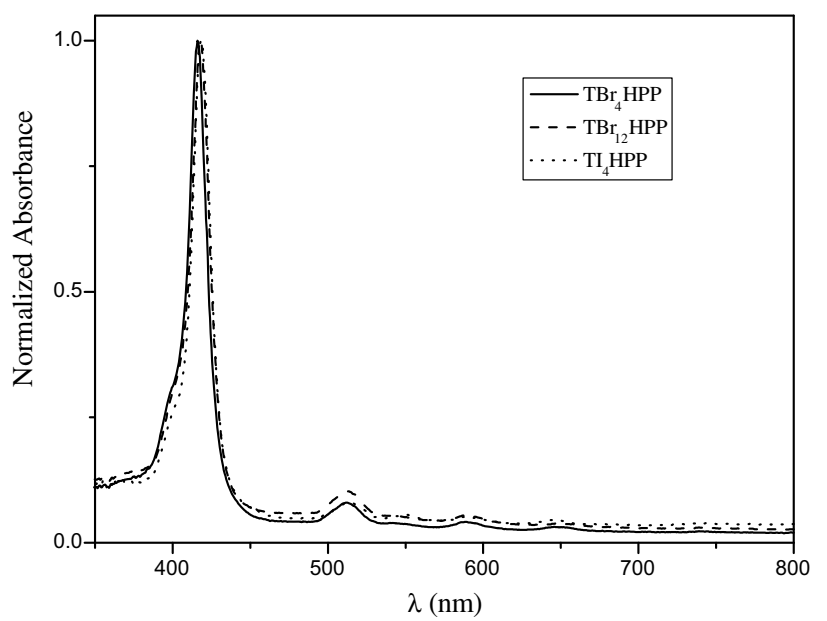

Fig. 1. UV-vis normalised spectra of $\mathrm{TBr}_{4} \mathrm{HPP}, \mathrm{TBr}_{12} \mathrm{HPP}, \mathrm{TI}_{4} \mathrm{HPP}$.
Table 2

Singlet oxygen formation quantum yields, photobleaching and $\mathrm{IC}_{50}$ values for sensitizers PS1-PS4 and Photofrin ${ }^{\circledR}$

\begin{tabular}{|c|c|c|c|c|}
\hline \multirow[t]{2}{*}{ Porphyrin } & \multirow[t]{2}{*}{$\Phi_{\Delta}$} & \multirow{2}{*}{$\begin{array}{l}\text { Photobleaching } \\
\text { (\% of remaining sensitizer) }\end{array}$} & \multicolumn{2}{|l|}{$\mathrm{IC}_{50}$} \\
\hline & & & WiDr Cells & A375 cells \\
\hline THPP, PS1 & 0.50 & 42 & $143 \mathrm{nM}$ & $115 \mathrm{nM}$ \\
\hline $\mathrm{TBr}_{4} \mathrm{HPP}, \mathbf{P S} 2$ & 0.55 & 67 & $113 \mathrm{nM}$ & $52 \mathrm{nM}$ \\
\hline $\mathrm{TI}_{4} \mathrm{HPP}, \mathbf{P S} 3$ & 0.58 & 22 & $>10 \mu \mathrm{M}$ & $2.3 \mu \mathrm{M}$ \\
\hline $\mathrm{TBr}_{12} \mathrm{HPP}$, PS4 & 0.50 & 19 & $>10 \mu \mathrm{M}$ & $>10 \mu \mathrm{M}$ \\
\hline Photofrin ${ }^{\circledR}$ & $0.53[36]$ & $\mathrm{nd}^{\mathrm{a}}$ & $666 \mathrm{nM}$ & $156 \mathrm{nM}$ \\
\hline
\end{tabular}

a Not determined.

There is an increment of the $\Phi_{\Delta}$ value with the incorporation of one bromine atom in the ortho position, in $\mathrm{TBr}_{4} \mathrm{HPP}$, as well as with one iodine atom in the para position of each phenyl ring, $\mathrm{Tl}_{4} \mathrm{HPP}$. With the presence twelve bromine atoms on the phenyl rings, $\mathrm{TBr}_{12} \mathrm{HPP}$, there is a decrease of $\Phi_{\Delta}$, being the same as described for THPP.

To study the photobleaching process we used the same experimental conditions, namely, solvent, concentration of the solution and light source, as those for the cytotoxicity assays. The absorption of the solutions was measured after $6,12,18$ and $24 \mathrm{~h}$ of irradiation. The decrease in intensity, measured by UV-vis spectroscopy, of THPP and $\mathrm{TBr}_{12} \mathrm{HPP}$ followed first order kinetics but $\mathrm{TBr}_{4} \mathrm{HPP}$ and $\mathrm{TI}_{4} \mathrm{HPP}$ showed a more complex behaviour. The photobleaching after completion of $24 \mathrm{~h}$ of irradiation is presented in Table 2 as a percentage of the remaining porphyrin.

Using the shake flask methodology we determined $\log P$, using the aqueous phase buffered at $\mathrm{pH} \mathrm{8,} \mathrm{of} \mathrm{THPP} \mathrm{(PS1)} \mathrm{as} 2.02$ and 3.54 for the sensitizer $\mathrm{TBr}_{4} \mathrm{HPP}$ (PS2). For PS3 and PS4 the concentration in the aqueous phase is below the detection limit of UV-vis spectroscopy.

\subsection{Cellular uptake}

The cellular uptake was dose-dependant, the fluorescence intensity decreases with the concentration of the initial solution of porphyrin used in incubation for all the sensitizers, as shown in Fig. 2 for THPP. The milligrams of protein was determined for 12 wells with an initial amount of $10^{5}$ cells and found to be statistically independent $(0.82 \pm 0.23 \mathrm{mg} / \mathrm{mL})$. In separated cellular extraction experiments using $5 \mu \mathrm{M}$ solutions the intracellular concentration was found to be $0.63 \pm 0.15 \mu \mathrm{M}$ for THPP, $1.88 \pm 0.11 \mu \mathrm{M}$ for $\mathrm{TBr}_{4} \mathrm{HPP}, 3.84 \pm 1.00 \mu \mathrm{M}$ for $\mathrm{TI}_{4} \mathrm{HPP}$ and $2.89 \pm 0.92 \mu \mathrm{M}$ for $\mathrm{TBr}_{12}$ HPP, Fig. 3.

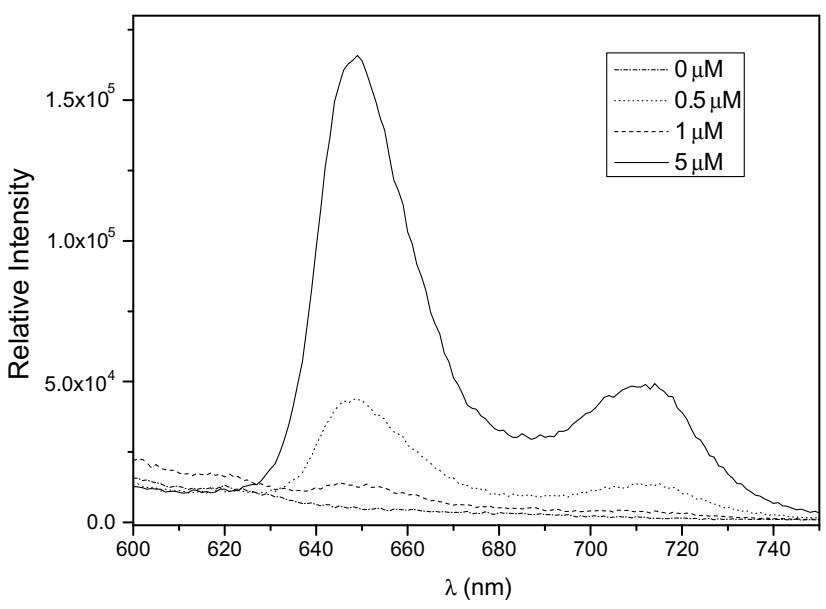

Fig. 2. Fluorescence spectra of THPP obtained after cellular extraction using drug solutions of $5 \mu \mathrm{M}, 1 \mu \mathrm{M}$ and $0.5 \mu \mathrm{M}$. 


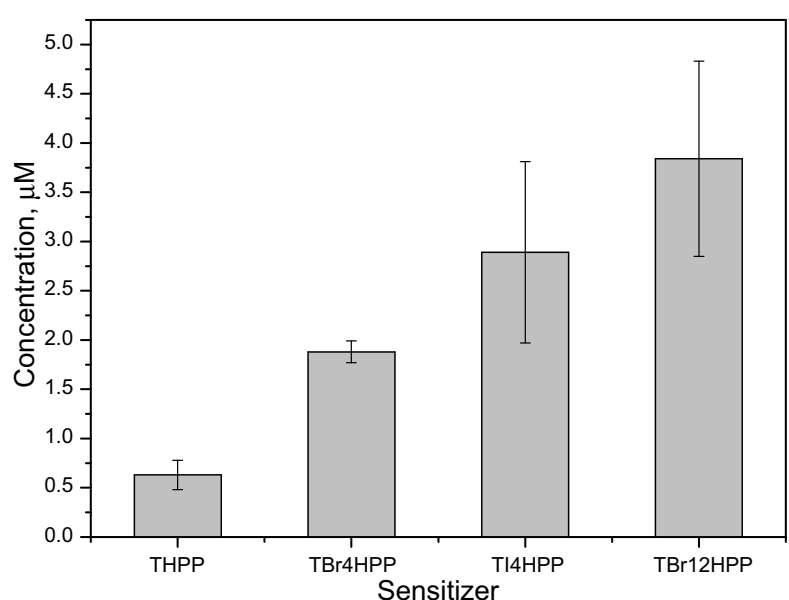

Fig. 3. Cellular uptake of sensitizers PS1-PS4.

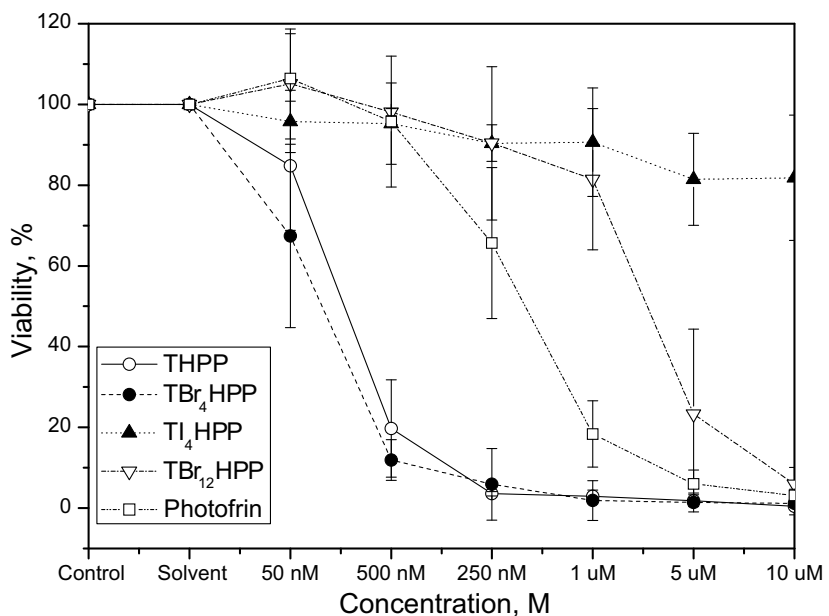

Fig. 4. Cell viability \% for WiDr human colon adenocarcinoma cells using sensitizers PS1-PS4 and Photofrin ${ }^{\circledR}$.

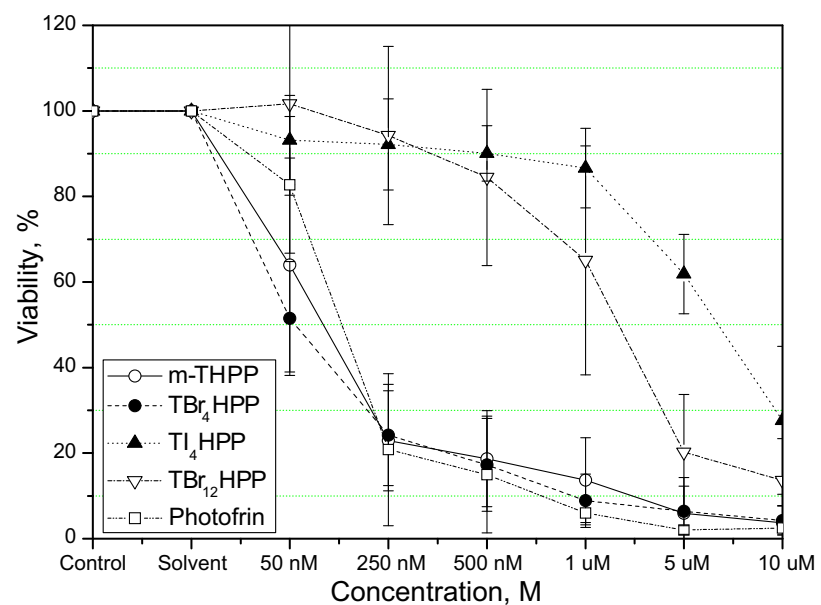

Fig. 5. Cell viability \% for melanoma A375 cells using sensitizers PS1-PS4 and Photofrin ${ }^{\circledR}$.

\subsection{Cytotoxicity assays}

The data of cell viability for different concentrations of sensitizer and $10 \mathrm{~J} \mathrm{~cm}^{-2}$ of fluence in WiDr human colon adenocarci- noma cells, is presented in Fig. 4 and the data corresponding to the same experimental conditions using melanoma A375 cells, in Fig. 5.

The $\mathrm{IC}_{50}$ values for dose/response curves for WiDr human colon adenocarcinoma cells and melanoma A375 are reported in Table 2 as well as the values obtained for Photofrin ${ }^{\circledR}$ as reference compound.

\section{Discussion}

PDT is an emerging treatment for diseases related to anomalous cell growth. The value of the treatment is directly dependant on the characteristics of the sensitizer. Searching for new sensitizers is an objective pursued by several groups because the performance of present drugs gives room for improvement.

Porphyrins with hydroxyl groups show good activity as sensitizers for photodynamic therapy. The presence of the hydroxyl in the meta position of the meso phenyl rings seems to enhance this activity relatively to other positions [25]. Patrice and co-workers reported a promising diaryl sensitizer with four hydroxyl groups (two in each phenyl group) [26,27]. Banfi et al. studied a series of 5,10,15,20-tetraarylporphyrins and 5,15-diarylporphyrins with different numbers of hydroxyl groups on the phenyl ring concluding that the compound with hydroxyl groups at the meta position are the most active in PDT [28].

Halogenated porphyrins have been studied as sensitizers in PDT; for fluorinated derivatives, superior photodynamic properties have been observed [29-31]. With other halogen atoms some reports confirmed the expected superior behaviour for singlet oxygen formation, as expected from the heavy atom effect $[8,32]$ but photocytoxicity was not studied.

The increase of the number of halogens on the phenyl ring or the substitution of bromine for iodine did not bring any significant changes to the absorption characteristics of this type of sensitizers, Table 1 . For the halogenated derivatives, the more significant transition for PDT applications ( $\mathrm{Qy}(0-0))$, is slightly shifted to the red accompanied by the decrease of the absorption coefficient.

The singlet oxygen formation quantum yield, Table 2, increases, with the presence of four bromine (PS2) or iodine atoms (PS3) on the phenyl ring of the porphyrin as expected due to an increase of the spin-orbit coupling with the heavy atom effect. The decrease of $\Phi_{\Delta}$ value with the insertion of more bromine atoms was already predicted for the $\mathrm{Zn}(\mathrm{II})$ complex of halogenated methoxyporphyrins [8]. The substitution in both ortho and para positions (PS4) has a negative effect on the singlet oxygen formation quantum yield. It is possible that this type of substitution increases the formation of the triplet state (ISC process) and also the radiationless transition of its decay, decreasing the triplet lifetime and therefore the interaction with oxygen.

The photobleaching of the sensitizer in photodynamic therapy has received increasing attention because sensitizer destruction could be a limiting factor of its activity $[33,34]$. Our sensitizers show very different photobleaching rates, varying with the nature and number of halogen atoms. At $24 \mathrm{~h}$ of irradiation the stability order is PS2 $>$ PS1 $>$ PS3 $>$ PS4, Table 2 . The poor stability of PS3 and PS4 can be related to the liability of the halogen-carbon bond in these sensitizers.

There is no significant photobleaching of these sensitizers under conditions of cytotoxicity assays using $10 \mu \mathrm{M}$ solutions. After the irradiation time corresponding to these experiments we estimate that the $\%$ of porphyrin remaining was $97 \%$ for THPP, $98 \%$ for $\mathrm{TBr}_{4} \mathrm{HPP}, 92 \%$ for $\mathrm{Tl}_{4} \mathrm{HPP}$ and $94 \%$ for $\mathrm{TBr}_{12} \mathrm{HPP}$.

The difficulties for determining the octanol/water partition coefficients of poorly amphiphilic porphyrins is already known [28]. We determined the $\log P$ of two of our sensitizers PS1 and 
PS2, the hydrophilicity decreases with the inclusion of the bromine atoms in the structure of the sensitizer, this effect is predicted by simple $\mathrm{ACD} / \log P$ (ChemSketch 10.0 ) calculations and probably is the reason for the incapability of the determination of $\log P$ of the other two sensitizers.

The cellular uptake increases with the presence of the halogen atom following the series: THPP $<\mathrm{TBr}_{4} \mathrm{HPP}<\mathrm{Tl}_{4} \mathrm{HPP}<\mathrm{TBr}_{12} \mathrm{HPP}$. As described by others, there is a relation between the lipophilicity and the cellular uptake but, as in our case, this is not directly related to the photodynamic effect. It seems that pharmacodynamic effects have greater influence than the pharmacokinetics of the porphyrins [35].

The sensitizers PS1 to PS4 showed no dark phototoxicity in $50 \mathrm{nM}$ and $10 \mu \mathrm{M}$ range of concentration. Only with irradiation of red light did we observe cytotoxicity (Figs. 4 and 5). Curves for cell viability for WiDr cells in PDT assays are generally shifted to the right relatively to the corresponding curves for melanoma cells for all sensitizers tested. This shows that WiDr cells are more resistant than melanoma cells to PDT treatment. For WiDr cells, PS3 and PS4 are less active than Photofrin ${ }^{\circledR}$ and PS1 and PS2 are more active and the same behaviour of phototoxicity is observed in the case of melanoma cells. For the two lines of cells, it is clear that the brominated porphyrin PS2 presents more phototoxicity than the non-halogenated PS1. From the curves of viability we can calculate the $\mathrm{IC}_{50}$ for the sensitizers, Table 2 .

The results showed that the porphyrin with four bromine atoms (PS2) presents an $\mathrm{IC}_{50}$ of $113 \mathrm{nM}$, that is about six times less than the $\mathrm{IC}_{50}$ of the Photofrin ${ }^{\circledR}$ and $25 \%$ less than the non brominated analog (PS1) against WiDr cell line. For melanoma cells PS2 has an even lower $\mathrm{IC}_{50}(52 \mathrm{nM})$ that is about three times lower than the $\mathrm{IC}_{50}$ for Photofrin ${ }^{\circledR}$ and two times lower than that of PS1.

Analysis of these results, comparing with THPP (PS1), points out that the iodine atoms in the para position increase the singlet oxygen formation quantum yield and the cellular uptake and decrease the photostability and the hydrophilicity of the molecule resulting in a poor photodynamic effect with $\mathrm{IC}_{50}$ values greater than Photofrin ${ }^{\circledR}$. The same is observed for the porphyrin bearing twelve bromine atoms. The presence of bromine atoms in the ortho positions of the phenyl rings shows the best balance of properties, increase of the singlet oxygen formation quantum yield, the cellular uptake, and photostability without major changes in the hydrophilicity. This set of characteristics leads to a phototherapeutic agent with better $\mathrm{IC}_{50}$ values against $\mathrm{WiDr}$ and $\mathrm{A} 375$ tumour cell lines.

\section{Conclusion}

Heavy atom effect was observed in the iodinated and brominated derivatives of THPP. The cytotoxicity over WiDr and A375 tumour cell lines is not directly related to the $\Phi_{\Delta}$ values of the sensitizers, probably because the solubility characteristics and the relationships structure-media and cellular-interactions play an important role in the cytotoxicity. The derivative with four bromine atoms (PS2) shows high singlet oxygen formation quantum yield ( $\left.\Phi_{\Delta}=0.55\right)$, similar solubility as THPP, higher cellular uptake and shows the best $\mathrm{IC}_{50}$ values, $113 \mathrm{nM}$ for WiDr cells and $52 \mathrm{nM}$ for A375 cells.

\section{Acknowledgements}

The authors thank Chymiotechnon, Ministério da Economia/ POE/Prime/Proj 3/293/CLARO, Faculdade de Medicina de Coimbra and CIMAGO for financial support and Gastroenterology service of HUC for equipment facilities. Mass spectra studies were carried out by M. Alexandra Rocha Gonsalves-Chymiotechnon.

\section{References}

[1] M.R. Detty, S.L. Gibson, R.W. Wagner, Current clinical and preclinical photosensitizers for use in photodynamic therapy, J. Med. Chem. 47 (2004) 3897-3915.

[2] I.J. MacDonald, T.J. Dougherty, Basic principles of photodynamic therapy, J. Porphyr. Phthalocyan. 5 (2001) 105-129.

[3] E.S. Nyman, Research advances in the use of tetrapyrrolic photosensitizers for photodynamic therapy, J. Photochem. Photobiol. B. Biol. 73 (2004) 1-28.

[4] R. Bonnett, Chemical Aspects of Photodynamic Therapy, Gordon and Breach Science Publishers, Amsterdam, 2000.

[5] R.R. Allison, G.H. Downie, R. Cuenca, X.-H. Hu, C.J. Childs, Photosensitizers in clinical pdt, Photodiag. Photodynam. Ther. 1 (2004) 27-42.

[6] R. Bonnett, P. Charlesworth, B.D. Djelal, D.J. McGarvey, T.G. Truscott Photophysical properties of $m$-THPP, $m$-THPC and $m$-THBC: a comparative study, J. Chem. Soc., Perkin Trans. 2 (1999) 325.

[7] R. Bonnett, R.D. White, U.-J. Winfield, M.C. Berenbaum, Hydroporphyrins of the meso-tetra(hydroxyphenyl)porphyrin series as tumour photosensitizers, Biochem. J. 261 (1989) 277-283.

[8] E.G. Azenha, A.C. Serra, M. Pineiro, M.M. Pereira, S.J. Seixas de Melo, L.G. Arnaut, S.J. Formosinho, A.M.d.A. Rocha Gonsalves, Heavy-atom effects on metalloporphyrins and polyhalogenated porphyrins, Chem. Phys. 280 (2002) 177-190.

[9] A. Gorman, J. Killoran, C. O’Shea, T. Kenna, W.M. Gallagher, D.F. O'Shea, In vitro demonstration of the heavy-atom effect for photodynamic therapy, J. Am. Chem. Soc. 126 (2004) 10619-10631.

[10] A.M. Beja, J.A. Paixão, M.R. Silva, L. Alte de Veiga, A.M.d.A. Rocha Gonsalves, A.C. Serra, 2-Bromo-3-hydroxybenzaldehyde Acta Crystallogr., C 56 (2000) 354-355.

[11] H.H. Hodgson, H.G. Beard, Bromo-derivatives of $m$-hydroxybenzaldehyde, J. Chem. Soc., Chem. Commun. 127 (1925) 875-881.

[12] K.C. Pandya, R.B.K. Pandya, R.N. Singh, Condensation of aldehydes with malonic acid. Part XXIV. m-Hydroxybenzaldehyde and seven of its derivatives, J. Indian Chem. Soc. 29 (1952) 363-367.

[13] E. Gandin, Y. Lion, A simple and convenient method of measuring the number of photons absorbed by a solution irradiated with polychromatic light, J. Photochem. 20 (1982) 77-81.

[14] R.W. Redmond, J.N. Gamlin, A compilation of singlet oxygen yields from biologically relevant molecules, Photochem. Photobiol. 70 (1999) 391-475.

[15] M. Hoebeke, J. Piette, A.v.d. Vorst, Photosensitized production of singlet oxygen by merocyanine 540 bound to liposomes, J. Photochem. Photobiol. B. Biol. 9 (1991) 281-294.

[16] C.D. Borsarelli, E.N. Durantini, N.A. García, Singlet molecular oxygen-mediated photooxidation of nitrophenolic compounds in water-in-iol microemulsions. A kinetic study, J. Chem. Soc., Perkin Trans. 2 (1996) 2009-2013.

[17] I. Scalise, E.N. Durantini, Photodynamic effect of metallo 5-(4-carboxyphenyl)10,15,20-tris(4-methylphenyl)porphyrins in biomimetic AOT reverse micelles containing urease, J. Photochem. Photobiol. A: Chem. 162 (2004) 105-113.

[18] E.I. Yslas, V. Rivarola, E.N. Durantini, Synthesis and photodynamic activity of zinc(II) phthalocyanine derivatives bearing methoxy and trifluoromethylbenzyloxy substituents in homogeneous and biological media, Bioorg. Med. Chem. 13 (2005) 39-46.

[19] X.C. Chen, L. Hui, D.A. Foster, C.M. Drain, Efficient synthesis and photodynamic activity of porphyrin-saccharide conjugates: targeting and incapaciting cancer cells, Biochemistry 43 (2004) 10918-10929.

[20] R.A.W. Johnstone, M.L.P.G. Nunes, M.M. Pereira, A.M.d.A. Rocha Gonsalves, A.C Serra, Improved syntheses of 5,10,15,20-tetrakisaryl- and tetrakisalkylporphyrins, Heterocycles 43 (1996) 1423-1437.

[21] K.M. Smith, Porphyrins and Metalloporphyrins, Elsevier Scientific Publishing Company, Amsterdam, 1975

[22] E.J. Corey, W.T. Taylor, A study of the peroxidation of organic compounds by externally generated singlet oxygen molecules, J. Am. Chem. Soc. 86 (1964) 3881-3882.

[23] Y. Usui, Determination of quantum yields of singlet oxygen formation by photosensitization, Chem. Lett. (1973) 743-744.

[24] F. Wilkinson, J. Brummer, Rate constants for the decay and reactions of the lowest electronically excited singlet state of molecular oxygen in solution, J. Phys. Chem. Ref. Data 10 (1981) 809-999.

[25] M.C. Berenbaum, S.L. Akande, R. Bonnett, H. Kaur, S. Ioannou, R.D. White, U.J. Winfield, Meso-tetra(hydroxyphenyl)porphyrins, a new class of potenttumour photosensitizers with favourable selectivity, Br. J. Cancer 54 (1986) 717-725.

[26] Y. Ferrand, L. Bourré, G. Simonneaux, S. Thibaut, F. Odobel, T. Patrice Hydroporphyrins as tumour photosensitizers: synthesis and photophysical studies of 2,3-dihydro-5,15-di(3,5-dihydroxyphenyl)porphyrin, Bioorg. Med. Chem. Lett. 13 (2003) 833-835.

[27] L. Bourré, S. Thibaut, M. Fimiani, Y. Ferrand, G. Simonneaux, T. Patrice, In vivo photosensitizing efficiency of a diphenylchlorin sensitizer: interest of a DMPC liposome formulation, Pharmacol. Res. 47 (2003) 253-261.

[28] S. Banfi, E. Caruso, L. Buccafurni, R. Murano, E. Monti, M. Gariboldi, E. Papa, P. Gramarica, Comparison between 5,10,15,20-tetraaryl- and 5,15diarylporphyrins as photosensitizers: synthesis, photodynamic activity, and quantitative structure-activity relationship modeling, J. Med. Chem. 49 (2006) 3293-3304.

[29] A.L. Gryshuk, Y. Chen, W. Potter, T. Ohulchansky, A. Oseroff, R.K. Pandey, In vivo stability and photodynamic efficacy of fluorinated bacterio- 
purpurinimides derived from bacteriochlorophyll-a, J. Med. Chem. 49 (2006) 1874-1881.

[30] A. Villanueva, E.N. Durantini, J.C. Stockert, S. Rello, R. Vidania, M. Cañete, A. Juarranz, R. Arranz, V. Rivarola, Photokilling of cultured tumour cells by the porphyrin derivative cf3, Anti-Cancer Drug Des. 16 (2001) 279-290.

[31] S.P. Songca, In-vitro activity and tissue distribution of new fluorinated mesotetrahydroxyphenylporphyrin photosensitizers, J. Pharm. Pharmacol. 53 (2001) 1469-1476.

[32] M. Pineiro, A.L. Carvalho, M.M. Pereira, A.M.d.A.R. Gonsalves, L.G. Arnaut, S.J. Formosinho, Photoacoustic measurements of porphyrin triplet-state quantum yields and singlet-oxygen efficiencies, Chem. Eur. J. 4 (1998) 2299-2307.
[33] T.S. Mang, T.J. Dougherty, W.R. Potter, D.G. Boyle, S. Somer, J. Moan, Photobleaching of porphyrins used in photodynamic therapy and implications for therapy, Photochem. Photobiol. 45 (1987) 501-506.

[34] R. Bonnett, B.D. Djelal, P.A. Hamilton, G. Martinez, F. VWierrani, Photobleaching of 5,10,15,20-tetrakis( $m$-hydroxyphenyl)porphyrin ( $m$-THPP) and the corresponding chlorin ( $m$-THPC) and bacteriochlorin ( $m$-THPBC). A comparative study, J. Photochem. Photobiol. B. Biol. 53 (1999) 136-143.

[35] B.W. Henderson, D.A. Bellnier, W.R. Greco, a. Sharma, R.K. Pandey, An in vivo quantitative structure-activity relationship for a congeneric series of pyropheophorbide derivatives as photosensitizers for photodynamic therapy, Cancer Res. 57 (1997) 4000-4007.

[36] R.W. Redmond, K. Heihoff, S.E. Braslavsky, G.T. Truscott, Thermal-lesing and phosphorescence studies, Photochem. Photobiol. 45 (1987) 209-213. 